University for Business and Technology in Kosovo

UBT Knowledge Center

UBT International Conference

2014 UBT International Conference

Nov 7th, 2:00 PM - 2:15 PM

\title{
Ottoman - Bizantin city case, Tirana - birth of a city
}

Ogri Mane

Polytechnic University of Tirana, ogri.mane@yahoo.it

Armand Vokshi

Polytechnic University of Tirana, armandvokshi@gmail.com

Follow this and additional works at: https://knowledgecenter.ubt-uni.net/conference

Part of the Architecture Commons

\section{Recommended Citation}

Mane, Ogri and Vokshi, Armand, "Ottoman - Bizantin city case, Tirana - birth of a city" (2014). UBT

International Conference. 23.

https://knowledgecenter.ubt-uni.net/conference/2014/all-events/23

This Event is brought to you for free and open access by the Publication and Journals at UBT Knowledge Center. It has been accepted for inclusion in UBT International Conference by an authorized administrator of UBT Knowledge Center. For more information, please contact knowledge.center@ubt-uni.net. 


\title{
Ottoman - Bizantin city case, Tirana - birth of a city.
}

\author{
Ogri Mane ${ }^{1}$, Armand Vokshi ${ }^{1}$ \\ 1 Polytechnic University of Tirana \\ ${ }^{2}$ Architecture Department, Faculty of Architecture and Urbanism, Albania \\ 1'ogri.mane@yahoo.it, ${ }^{2}$ armandvokshi@gmail.com
}

\begin{abstract}
The expansion of Islam did multiply the number of cities to the edge of the desert, transforming the nomadic tribes in urban populations. For a good Muslim cannot be a better practice of the religion if not in the city, in the "Friday Mosque" for common prayers. Life in the city is considered a condition of moral perfection and been fixed in one place, giving up the nomadic life.

The urban culture in Islam is formed and developed through a series of contributions, derived from the traditions of construction and urban structures of the pre-Islamic city. Arabia and the countries of first conquest, gravitated into the orbit of Hellenistic and Roman world on one hand, and on the other on the Persian world orbit. Inside the ancient pattern, appeared new elements that will become hallmarks of the Islamic city: the palace, the mosque and the rows of shops that prefigure the 'souks' of more mature urban forms. The Islamic urbanism rejects any intentional and planned process, in which the city would be first designed and then implemented. The city had always been a spontaneous creation for the Muslim community. Everything will continue to persist even after the advent of Islam, with the addition of the religion and politics. Islam is a religion of the creative city: the very choice of the site is determined by religious factors.

Tirana was born as an variation of an Islamic city typology. Through the years appeared various urban typology design in Albanian territory. A part of the Islamic city tissue was replaced. Analyzing and understanding how the city has been created, explains how it function. In this way we understand the importance of this urban tissue which we can still find in Tirana.
\end{abstract}

Keywords: Tirana, Islamic city, Urban identity, Culture.

\section{Introduction}

The city of Tirana has a very dynamic urban history. This can easily be seen by investigating the current road system of Tirana. This paper will make a further step analyzing the birth of Tirana and the main characteristics of this town. In the first stage we make a description of the urban system with Islamic background and his transformation into an urban system which is called Ottoman-Byzantine. This urban system has much in common with Islamic city system but with its own features. The second part of the article focuses on describing quickly the main elements of Tirana. In the third stage are expressed some personal conclusions of the authors.

\section{Tirana un Ottoman-Bizantin city.}

Balkan has been, in a large well-known historical era, a combination of cultures, an intermediate zone between East and West. Albania is positioned in west of the Balkans and stays as a border state between two different cultures and is constantly influenced by both cultures. By the year 1478, before the Ottoman conquest, Albania shows a Western civilization greatly influenced by Greek-Roman culture. This has led to the creation of cities that match the basic characteristics of Greek and Roman cities. In 1478, after a long resistance, Albania falls under the occupation of the Ottoman Empire. From this 
moment Albania (at that time Arbëria) was affected for 500 years by an Islamic religious-based culture, which brings with it, new systems of organization and design of cities. Tirana, as we know it nowadays, is an urban space that takes place at the city level in the period of Ottoman domination of Islamic culture. If we try to lay it in a familiar urban pattern we may say that Tirana is developed as an Ottoman Byzantine city model.

\subsection{Charateristic of Ottoman-Bizantin city.}

It is the model of the Byzantine-Ottoman city that descends from the Islamic city of the Arab world, present along the arc of coastline stretching from the slopes of the Balkan to Anatolian. The term comes from the chronicles of the many voyages du Levant, in the late eighteenth and early nineteenth century, which tell the "Turkish-ottoman", "Turkish-Byzantine" city as an urban form with the disarticulation of the city in districts centered on a religious institute, with civic functions assumed by the great monasteries, with a conception of spatiality in harmony with nature and with the characters of the site. The following describes the character of the city as it has developed in the eighteenth and nineteenth century during the Ottoman period. The Ottoman city opens with no precise boundaries between country and town. This results in a greater articulation and interpenetration between the parties and between urban and rural areas that materializes the relationship between solids and voids being an integral part of each other. The city is the administrative and zipper exchange between the state and the country: the cities are the building blocks of an economic system based primarily on the agricultural system and handcrafted.

The diagram is "open" so that the city of the Levant spreads in rural overcoming the contrast with the traditional countryside typical of walled towns in Europe and arabo-islamic. The spatial organization maintains in appearance the same morphology of the Islamic city with mosque and its extensions to the social and cultural services that become central functions with a characteristic of monumentality, with the lack of regulations, but differs in certain significant aspects. As it says Maurice Cerasi "the center does not consist of a single point-symbolic place; the centrality shatters into many symbols and places: shopping center and central religious represented by large monumental complexes". Relations with the region are identified along a few lines, sometimes two that connect the city to the hinterland. There is radiality axis of penetration, the road structure is unequal, there is lack of an overall order and is characterized by a tight weave in the center which then thins out towards the periphery. That view hardly offers a harmonious reading of his site plan. A main street crosses, linking the city gates, or in coastal cities with port along this axis are located the main markets and han. The origin of this axis, often dating back to the pre-Ottoman period is the result of moving the center of gravity of the ancient commercial and functional urban core. When we define the Ottoman city without rules is thought mainly to the absence of road layouts with precise shape, the absence of the design of the form given by a walled city surrounded by squares and elements that lead scholars to the identification of a distinct urban morphology that leads to the definition of a city project. The city streets are narrow Ottoman, irregular, associate walled gardens and houses, in a design difficult to read according to a principle that refers to a 'harmonious articulation'. Not being able to speak a single center and representative body, the heart of the city consists of the area of the market (Çarşi) with regard to the daily relationships and exchanges. The market is the place of the public life, anything that does not fall under private or religious Çarşi is synonymous with the public, and here we'll find men and women of all social groups. The various functions of the public and economic life interpenetrate in space and ideology. Certainly the practice of Islamic mosque (xhami, cami) is the appointed place of the community (camiya, cemaat) and that by transposition institutional addressed other religious communities, Christians and Jews, to build up around their places of worship contributes to 'unification of public life. A central place in public relation exists but is rather business districts which in small and medium cities are associated with the main mosques. For the collective activities of exchange and relationships it can be said that the center of the 
city is made up of the Ottoman market, next to it are placed the mosque and the bathroom and not vice versa.

The principle feature of the morphology of the Ottoman city is the separation of the economic and residential ones, so they form zones or building complexes related to three main functional groups: residential, commercial and religious-cultural activities. The house and its context, mahalle, are separate units from the workplace and constitute a sort of elementary cell of settlements date from the aggregation of dwellings around a religious building. Mosques and churches are together at the coffee place, the center of each residential neighborhood (mahalle) and give him his identity. Characterization of identity that is also given to the market from his mosque, and when it comes to a small or medium sized city, it is here that the Friday mosque was built on, the main place of worship. The religious collective complexes stand out for their emerging architecture. They are never localized in front road facade, as in the case of European cities, living in symbiosis with the world of work and residence, through their courts, like in the churches in Byzantine cities. The articulation of the parts of the city is still characterized by ethnic division, which led to the different ethnic groups living in different areas. Many plans of cities have been drafted defining parts of the city by ethnicity of their inhabitants: Greek district, Armenian Quarter, Turkish quarter, Bulgarian district (in the case of Tirana according to families - Stërmasi, Mujos ect ...). There is a constant factor in distribution of city areas, it was almost always related to the development trends of social, cultural and historical periods. Also they were related to environmental change, structural and economic aspects of the city.

\subsection{Tirana the first urban nucleus.}

The first nucleus of the city emerged and grew together with the Old Mosque of Sulejman Pasha in central structure of Tirana, at the region intersection of major transit trade arteries. Along with the mosque there were built some other buildings, among them those of feudal family and their relatives, on the right bank of Lana river. Further in a distance of 50-60 meters west of the mosque was built a bakery shop, a public restroom and a dosshouse, three important items that affected services in shopping area.

The other nucleus are conected with the construction of the new Mosque as:

1. The Old Mosque

2. The Mosque of Fires

3. The Mosque of Zajmit

4. The Mosque of Haxhi Etehem Beut

5. The Mosque of Stremasit

6. The Mosque of Karapicit

7. The Mosque of Bërxollit

8. The Mosque of Mujos

9. The Mosque of Recit 


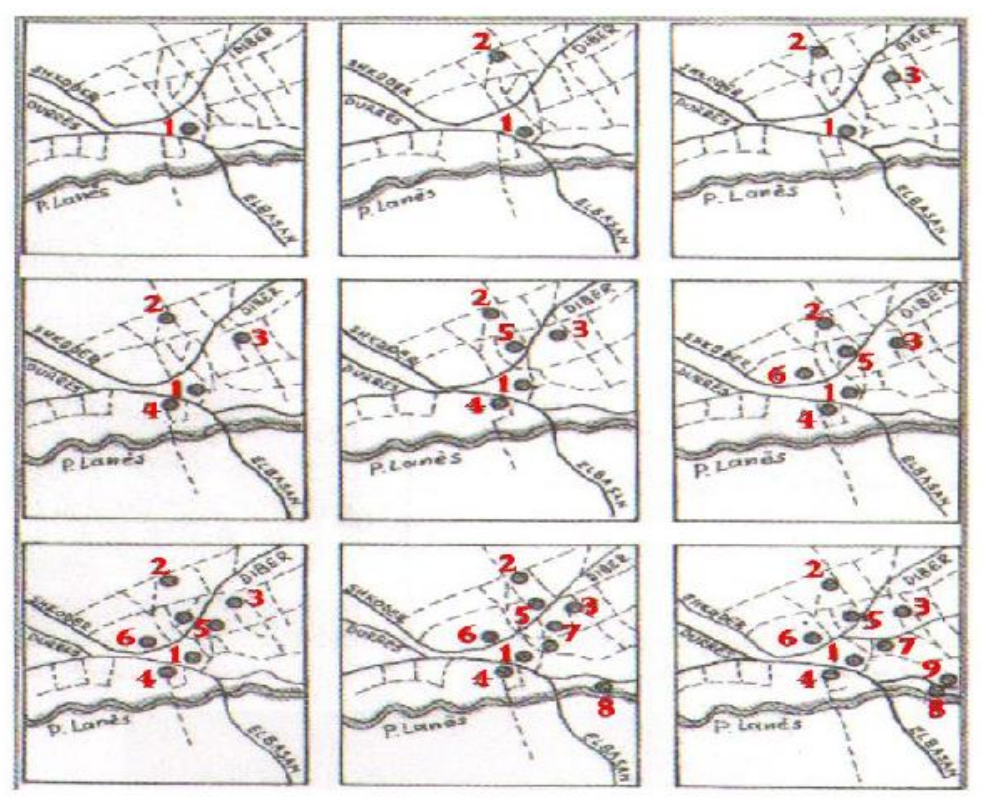

Fig. 5. The Mosques of Tirana $1614-1912$

"With the continued economic revitalization and growth without disrupting trade exchanges between the cities and villages of these areas, Tirana became not only local but also interregional economic center.

The heart of the city was defined from the Old Mosque and the square around it. We can say that today's "Barrikada" street, formerly named the Bazaar way (rruga e carshisë), constitute the main axis of the urban structure of the city. Along "Barrikada" street, six other tekke were lined up beside the Old Mosque. One of them, the Tekke of Shah Muharram of the halveti order, was very close to the mosque, in the roadside, on the east side of the "Barrikada" street ". The other five were lined up along the road in its western side - the Shah Bazaar Tekke, Shah Dyrrit Tekke (Harasani), the Firres Mosque, Dervishe Hatixhe Tekke and at the end of Kodra e Kuqe Mosque. Each of them form a civic residential area, which extended into the east side of the "Barrikadave" street. On the west side of the road axis, in the center, there was the Carshia, later called the Old Bazaar (Pazari i Vjetër). Carshia consisted of craft shops and traders, besides the warehouses and two dosshouses. They were placed in some roads sides within it. Shops had turned the backside to the streets of the city, forming a protective wall. This "surrounding" wall consisted of back shops incision at four points, which served as Carshi's entrances. Later when feudal anarchy was overcome and public order was settled, with the rise of the Old City Center space, shops were built on the backs of the shops mentioned earlier, but with their main facades toward the city streets, and in some sectors there were built residential houses. Carshia was bordered by Old Mosque, Mosque of Ethem Bey, Karapici Mosque and the Sheh Bazzar Tekke. Later in 1840 within the Carshi the Stërmasi Mosque was built" 


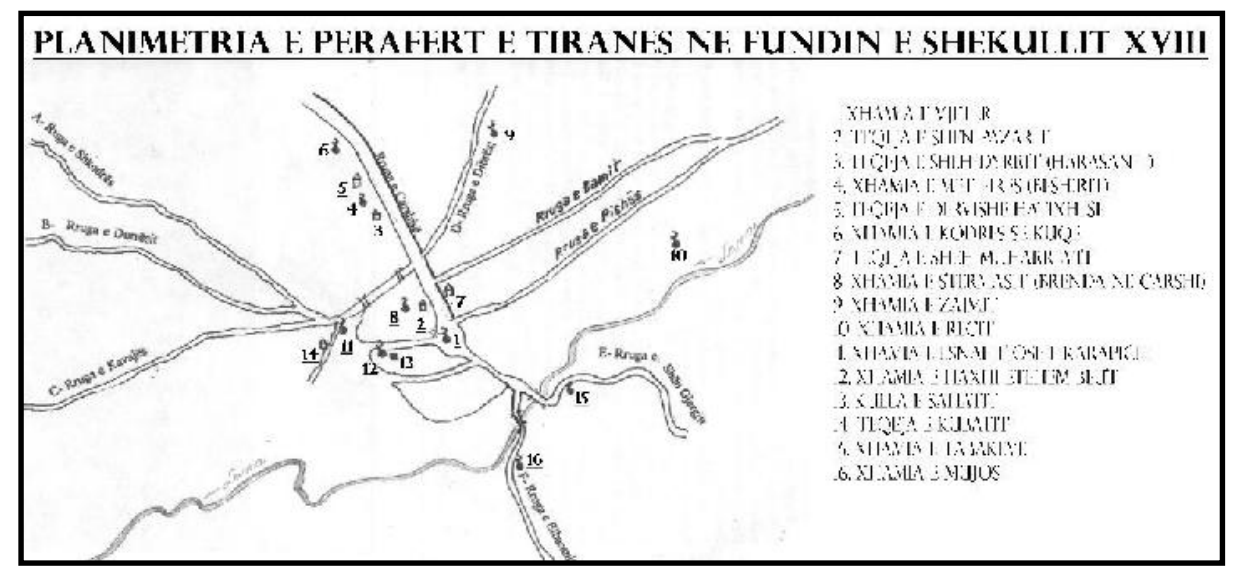

Fig. 2. Tirana plan in the XVIII sec.

Near the Carshi (Bazzar) on the west side, in the field, (today Scanderbeg Square) was held the weekly rustic bazaar on Thursdays.

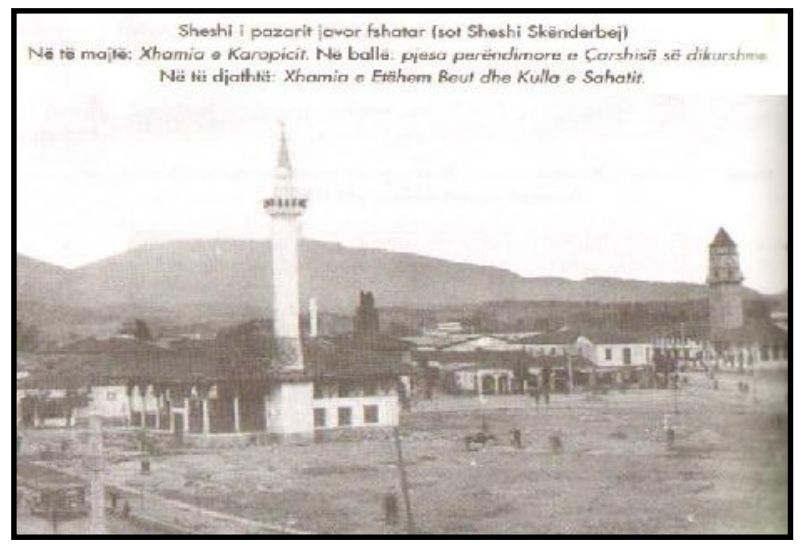

Fig. 3. Scanderbeg Square betwen $1920-1940$.

\section{Conclusion}

In conclusion of this brief article, the authors are convinced that Tirana represents many things in common with the type Ottoman - Byzantine cities. This is very clear in some features as follows:

1. Lack of a physical partition (wall) between the country and the city.

2. Grouping and formation of residential areas with common surname (family at large) around a mosque of the same name. 
3. Organic road system characteristic of Islamc cities.

4. Clear separation of functional areas in the city between three basic functions: (1) commercial area ( Pazari or Carshia) - (2) religious site (Xhamia) - (3) resdential area (Mëhallë).

Nowadays in Tirana these city features still exist. They appear in very difficult living conditions, due to the fact that they are announced "Historical area" and there could be not any intervention, accept restorations. These interventions are urgent and very expensive, regarding the building materials. It would be a luxury to Tirana and its citizens to preserve these areas as evidence of a rich and dynamic history of the city.

\section{References}

1 Frashëri, K.: Historia e Tiranës si qytet deri më 1920, 1st vol. Toena (2011)

2 Alaj, B. Lulo, K. Myftiu, G.: Tirana, sfida e zhvillimit urban.

3 Gusti, M.A.: Albania architettura e citta'. Maschietto editore (2009)

4 Cuneo, P.: Il mondo islamico, Laterza (1986)

5 Duby, G. : Gli Ideali del Mediterraneo, Mesogea (1997)

6 Lapidus, I.M.: Storia delle società islamiche (3 volumi), Einaudi 1994

7 Benevolo, L.: La città nella storia d'Europa, Editori Laterza (1993)

8 Benevolo, L.: Storia della città, Editori Laterza (1987)

9 Roncayolo, M.: La città, Einaudi (1988)

10 D.Autors. :Il mondo islamico. Immagini e ricerche, Storia della città n. $46 \backslash 1989$ Electa periodici

11 Cerasi, M.: Il tessuto residenziale della città ottomana (sec XVII e XIX), Storia della città n. 3132\(1985), Electa periodici

12 Cerasi, M.: La città del Levante. Civiltà urbana e architettura sotto gli Ottomani nei sec. XVII eXIX, Jaca Book (1988) 